UDC 339.97

DOI 10.33111/iep.2018.29.05_eng

\title{
Regional Associations In Global Economy
}

\section{SVITLANA RADZIYEVSKA ${ }^{1}$}

ABSTRACT. The present article deals with the current state, interrelations and prospects for the development of key regional associations of global economy. It defines main factors of development of regional associations in the latter half of the 20th century - at the dawn of the 21st century: the end of the Second World War; implementation of information and communication technologies; the end of cold war between capitalist and socialist countries. The article also covers the issue of leading role of the USA in the initiating and development of integration processes in Europe and Asia. It emphasizes the role of «Marshall Plan» in the development of integration processes and in the achievement of status of primary currency of international settlements by the American national currency, US dollar. It is being noted that the influence of the USA on African, Latin American and Asian countries was greatly promoted due to loss of colonies by West European countries as a result of national liberation struggle. The article also reveals the connection between integration processes and the establishment of two military and political blocks - in capitalist and socialist countries, NATO and Warsaw Pact Organization. Nineteen regional and trans-regional associations forming the basis of global economic system at the dawn of the 21st century were selected and analyzed. The associations being investigated include thirteen regional integration associations established on the basis of regional trade agreements on creation of free trade zone belonging to the continents of Eurasia, North and Latin America, Africa; inter-governmental organization SCO; trans-regional integration associations TPP, RCEP and T-TIP, transcontinental associations APEC and BRICS. NAFTA is a most powerful association; EU is the most developed; maintenance of leading role of the USA in global economy and consolidation of role of PRC, India, EU and Brazil, as well as aggravation of competition between the USA and China in their influence on Asian, Latin American and African countries is observed. On the one part, transcontinental associations TPP, T-TIP and APEC were established for the purpose of furtherance of interests of the USA, consolidation of their leading role in global economy, while, on the other part, the trans-regional association RCEP and global initiative «One belt, one road» were established for consolidation of position of PRC. BRICS project implements the interests of leading countries of three continents in their relations with USA and EU, for optimization of which the system of consensual regulation of global economy. The article accentuates that for the purpose of prevention of conflicts and collisions it is necessary to pivot from the existing ideology of maximization of satisfaction of material needs that will always lead to rise in inequality due to lack of availability of resources for production of goods and services.

KEYWORDS. Regionalism, integration associations, trans-regional associations, transcontinental associations, NAFTA, EU, ASEAN, TPP, RCEP, T-TIP, APEC, BRICS, free trade zone, customs union, common market, economic and monetary union, worldwide regulation.

\section{Introduction}

The end of XX century - the dawn of the XXI century is characterized by acceleration of processes of globalization and regionalization of global economy. Years of establishment of

*This article was translated from its original in Ukrainian

${ }^{1}$ Svitlana Radziyevska - Ph.D. in Economics, Ph.D. in Philological Sciences, Associate Professor, Associate Professor of the Logistics and General Economic Knowledge Department of the State Economy and Technology University of Transport. Sphere of scientific interest: global economy and trends of its development, financial aspects of globalization, techno-globalism. E-mail: radzievskaya@yahoo.com.

IEP, № 29, (2018) pp. 105-131

(C) Svitlana Radziyevska, 2018 «All rights reserved»

ISSN 1811-9832/2018/№ 2 (29) 
international institutions - International Monetary Fund (IMF), World Bank (WB), as well as the General Agreement on Tariffs and Trade (GATT) on the basis of which the World Trade Organization (WTO) was created - the institutions of global level the functioning of which is heavily criticized by scholars both within the country and abroad, shall be considered to be the beginning of development of globalization processes $^{2}$.

The development of regional integration associations was caused: firstly, by the end of the Second World War; secondly, by the development of scientific-and-technological advance that provided the widespread implementation of information and communication technologies, having «squeezed» the planet and thus facilitating the establishment of relations between the states; thirdly, the end of cold war between the countries of camp of socialism and capitalism that resulted in the victory of the latter.

In 1948 sixteen European states decided to use assistance offered by the USA, the most powerful state across the globe after the end of the Second World War, and received over 12 billions of US dollars within four years, whereof the Great Britain received 26\%, France - 18\%, German Federal Republic $-11 \%{ }^{3}$. USSR withdrew from participation in the «Marshall Plan», while the West European countries started to restore their economy, cooperating actively both with the USA and with each other. Dollar credits extended to many of the countries transformed the national currency of the USA to the principal currency of international settlements. At the same time, the «Marshall Plan» solved a problem of increase in demand for the American products abroad. Geopolitical situation in the world caused the initiation of integration processes in Europe, in which the USA was engaged to the fullest extent possible ${ }^{4}$.

The USA also announced an initiative of the implementation of integration processes in Asia, also accompanied by the provision of the financial assistance. So, Japan, a recent enemy and an affected party in the Second World War, became the ally of the USA and the leader in the region. Moreover, Japan acted as one of three centres of global economy within the sufficient period of time. Japan, like other

\footnotetext{
${ }^{2}$ Trade and development report 2017. Beyond austerity: towards a global new deal. Overview. - UNCTAD. New York and Geneva, 2017. - P. 23-29.

${ }^{3}$ The Marshall Plan and the establishment of the Organization for European Economic Cooperation // Historical events in the European integration process (1945-2014). Available at: http://www.cvce.eu

${ }_{4}$ The European idea // Historical events in the European integration process (1945-2014). Available at: http://www.cvce.eu
} 
European countries, that participated in «Marshall Plan» obtained an appropriate economic assistance ${ }^{5}$.

Developing the block strategy, oriented to the prevention of communistic threats, the USA also initiated the establishment of the range of military and political blocs in the regions, to which the attention of the USSR was attracted. The first - after NATO - such bloc was established in the area of the Pacific ocean in 1951 - Pacific Security Pact; in 1954 it was established in South and Eastern Asia; in 1955 it was established within the Great Britain, Turkey, Iran, Iraq and Pakistan ${ }^{6}$.

And if the USA was the initiator of regional integration processes in the western world, then the USSR was the initiator of such processes socialism countries. So, the Council of Mutual Economic Assistance was established in 1949 for the purpose of national economy recovery and the development of multilateral economic cooperation. This Council included the USSR, the People's Republic of Poland, Czechoslovak Socialist Republic, the People's Republic of Hungary, Socialist Republic of Romania, People's Republic of Bulgaria and the People's Socialist Republic of Albania. Later the Council of Mutual Economic Assistance also included the German Democratic Republic, Vietnam, Cuba and Mongolia. So, if 73\% from general foreign trade turnover of Bulgaria, Hungary, Poland, Romania and Czechoslovakia accounted for the Western Europe, 15\% accounted for the mutual exchange, and 1\% accounted for the USSR, then 18, 27 and 40\% accounted for in 1958 year respectively. Albania withdrew from the association in 1961. the Council of Mutual Economic Assistance functioned before 1991 and ensured the arrangement of socialist economic integration ${ }^{7}$.

So, the regional integration processes were initiated through establishment of two competitive blocs of the states after the end of the Second World War, and each of these blocks tried to draw the members from other camp over to its side.

The integration processes took centre stage in Eurasia, the continent where both world wars began. At the same time, the situation on the East of Asia became complicated, as China, Mongolia, North Korea and Vietnam strengthened their sovereignty and became socialist countries. The USA supported Japan, South Korea and Taiwan. The influence of the USA on Latin American, African and Western Asian countries was greatly promoted due to loss of colonies by West European countries. As a result of national liberation struggle of the former colonies the large part of them earned the

\footnotetext{
${ }^{5}$ Wallerstein, I.(2007). Globalization or the age of transition? A long-term view of the trajectory of the worldsystem. Globalization and Economy. Vol. 1. Globalizing Markets and Capitalism. Ed. by P. James, B.K. Gills. Los Angeles: Sage publications, 2007 (Central currents in globalization): 401-416.

${ }^{6}$ Kalashnikov, A.V. (2005). Confrontation between NATO and Warsaw Pact (1949-1991): dissertation for PhD in History. Lviv: National University «Lviv Politechnics». [in Ukrainian].

Butorina, O.V.. \& Kaveshnikova, N. Yu. (2017). European integration. Moscow: Aspect Press. [In Russian].
} 
status of the Third World Countries and became the object of influence of both blocs of the states - both headed by the USSR and the USA.

After the loss of cold war by the USSR and its allies the group of states - former colonies earned the status of the developing countries or the South, and former socialist countries earned the status of transitive countries, i.e. the countries that transit to market capitalist economy. Global capitalist system prevailed in the world after the end of cold war, and the national states of the countries were divided into: developed capitalist countries, transitive countries and the developing countries. The world get the name of postbipolar unipolar and became the global capitalist world with unipole of the USA.

Recently the scholars both within the country and abroad accentuate on weaknesses of capitalism, on the defects of the system of economic life of the society, formed on the basis of free market ideology $(\text { Liberalism })^{8}$. This criticism emerged full blown after emergence of global problems, caused by the first global financial crisis of the years $2008-2010$, when the defining role of the financial sector in the course of global processes became obvious ${ }^{9}$.

The structural transformation of the world became necessary, and, according to the opinion of some scholars, this transformation is already accompanied by: 1) transit from two-polar to multi-pole or three-pole structure and new redistribution of power and new specialization of labor related to it; 2) gradual decrease of hegemony of the USA with their rather favorable attitude toward regionalism; 3) erosion of the Westphalian system, national state, growth of mutual dependence and «globalization», change of attitude toward neoliberal development and proper political system in the developing countries and post-communist countries ${ }^{10}$.

On the one part, the problems of such level have to be solved, focusing on the issues of configuration of power at worldwide level. However, on the other part, some scholars select the state as the main player of international relations to be their target of research. Moreover, we believe, that we have to agree with the specialists - regionalists who prove the importance of study of special aspects of functioning of regional blocs of the countries under the conditions of modern

\footnotetext{
${ }^{8}$ Amin, S. (2010). Exiting the crisis of capitalism or capitalism in crisis. Globalizations. Vol.7, Issue 1-2: 261273.

Bone, J. (2012). The deregulation ethic and the conscience of capitalism: how the neoliberal 'free market' model undermines rationality and moral conduct. Globalizations. - 2012. - Volume 9, Issue 5: 651-665.

Robinson, W.I. (2013). Global capitalism and its anti-'human face': organic intellectuals and interpretations of the crisis. Globalizations. Volume 10, Issue 5: 659-671.

${ }_{9}$ Radzievska, S. (2016). Global Crisis, financialization and technological development. International Economic Policy. №24: 124-154.

Hettne, B. \& Soderbaum, F. (2000). Theorising the rise of regionness. New Political Economy. Vol. 5, Issue 3: $457-472$.
} 
globalization ${ }^{11}$, emphasizing the key role of trend of regionalization in the formation of modern multipolar global regime ${ }^{12}$.

The development of new forms of trans-regional cooperation is one of the structural transformations of international economic relations at this stage. So, modern regionalism is represented not only by the states as the basic core members of this process, but also by the great number of various institutions, organizations, business leaders. Regionalism covers two or more regions by cooperation under the conditions of globalization; it is characterized by substantiation of reasonability of unification of partnership of several groupings, taking on a form of interregionalism and transregionalism ${ }^{13}$.

Many papers of scholars both in Ukraine and abroad were devoted to the most diverse aspects of the establishment and functioning of regional associations: O. H. Bilorus ${ }^{14}$, O.V. Bulatova ${ }^{15}$, Ya. Vitkovska ${ }^{16}$, I.Yu. Huzhva $^{17}$, N.V. Kryvenko ${ }^{18}$, D.H. Lukianenko ${ }^{19}$, V.I. Muraviov, V.Ye. Novytsky ${ }^{20} \mathrm{i}$, V.O. Petukhova ${ }^{21}$, Ye.V. Saveliev ${ }^{22}$ and A.I. Krysovatyi, A.P. Rumiantsev ${ }^{23}$, S.E. Sardak ${ }^{24}$, V.R. Sidenko ${ }^{25}$, I. Taylor ${ }^{26}$, H.

\footnotetext{
${ }^{11}$ Mittelman, J.H. (2013). What's in a name? Global, international and regional studies. Globalizations. Volume 10, Issue 4: 515-519.

Green, J.K. (2016). Rising powers and regional orders: China's strategy and cross-strait relations. Globalizations. Volume 13, Issue 2: 129-142.

Shnyrkov, O.I., Filipenko, A.S., \& Rumyantsev, A.P. (2013). Free trade areas at the beginning of $21^{\text {st }}$ century: monograph. Kyiv: Kyiv University. [in Ukrainian].

${ }^{4}$ Bilorus, O.G. (2016). The economic globalistics. The world system of globalism. Kyiv: University «Ukraine». [In Ukrainian]

Bulatova, O.V. (2012). Regional component of the global integration processes: monograph, Donetsk: Donetsk National University. [In Ukrainian].

${ }^{16}$ Witkowska, J. (2016). Integration processes in the global economy: current state and prospects. The cases of the European Union, ASEAN Economic Community, and NAFTA. Comparative Economic Research. Vol.19, № 4: $47-65$.

${ }^{17}$ Guzhva, I. Yu. (2016). Ukraine's participation in free trade and the possibilities of adaptation of the national economy to the conditions, formed as the result of the megaregional trade blocks formation. Scientific Bulletin of the International Humanitarian University. Series: Economy and management. Odessa. Vol.15: 12-16. [in Ukrainian].

${ }_{18}$ Kryvenko, N.V. (2017). The peculiarities of the development of integration blocs. Scientific notes of the National University of «Ostroz'ka academy». Series «Economy». Vol. 6(34): 4-7. [in Ukrainian].

${ }^{19}$ Lukianenko, D.G. Global economic integration. Kyiv: National textbook, 2008. [In Ukrainian].

${ }^{20}$ Novitsky, V.E. (2004). Economic resources of civilization development. Kyiv: National Aviation University. [in Ukrainian].

Novitsky, V.E. (2007). Regulation strategies of the open economic systems and global competition for resources. Economy of Ukraine. Vol.7: 4-14. [in Ukrainian].

${ }^{21}$ Petukhova, V.O. (2016). Analysis of foreign trade relations of the national economies and Ukraine in the global system of international trade. Scientific Bulletin of Uzhhorod National University. Series: International economic relations and world economy. Vol. 6, part 2: 149-155. [in Ukrainian].

${ }_{22}$ Bulatova, O., Kozak, Yu., Krysovatyi, A., Savel'ev, E. (2014). New world economic order and global challenges for Ukraine: monograph. Ternopil: Ternopil National Economic University. [in Ukrainian].

3 Shnyrkov, O.I., Filipenko, A.S., \& Rumyantsev, A.P. (2013). Free trade areas at the beginning of $21^{\text {st }}$ century: monograph. Kyiv: Kyiv University. [in Ukrainian].

${ }^{24}$ Sardak, S.E. (2016). The potential of economic development of ASEAN. Eastern Europe: economy, business and management. Vol.5(05): 41-44. [In Ukrainian].

${ }^{25}$ Sidenko, V.R. (2011). Globalization - European integration - economic development: Ukrainian model. In two volumes. Kyiv, Fenix Publ. Volume 2: European integration and economic development. National Academy of Sciences of Ukraine; Institute for Economics and Forecasting. [In Russian].
} 
Wallace $^{27}$, I.V. Us ${ }^{28}$, A.S. Filipenko ${ }^{29}$, V.I. Chuzhykov ${ }^{30}$, I. Shen ${ }^{31}$, O.I. Shnyrkov ${ }^{32}$ etc $^{33}$. These papers present the stages of integration, establishment and functioning of regional associations. However, the prospects of regionalization of global economy in the context of interrelations of leading countries and regional associations have to be covered.

The purpose of the article is the analysis of leading regional associations, identification of the most powerful associations and countries in economic terms, research of interrelations between them for definition of prospects of regionalization of global economy.

\section{Key regional economic groupings of modern times}

Theory of regional integration that develops under the conditions of new regionalism reveals the special aspects of the region not only as the territorial entity, but also the functional structure. Special scientific literature considers regionalism as a well-ordered, multilateral mutual dependence controlled by the states within regional space, resulting in various certain regional projects and institutions corresponding to them $^{34}$.

Leading regional associations of global economy were selected on the basis of statistical information in reference books, scientific publications, with due regard to the necessity of coverage of all continents and selection of the most important from them. We selected nineteen regional associations: thirteen associations are regional

\footnotetext{
${ }^{26}$ Taylor, I. (2003). Globalization and regionalization in Africa: reactions to attempts at neo-liberal regionalism. Review of International Political Economy. Vol. 10. Issue 2: 310-330.

${ }^{27}$ Wallace, H. (2000). Europeanisation and globalisation: complimentary or contradictory trends? New Political Economy. Volume 5, Issue 3: 369-382.

${ }^{28}$ Us, I.V. On peculiarities of the foreign economic policy of Ukraine in the conditions of creation of new integration mega-blocks. Analytical notes. Available at: http://www.niss.gov.ua/articles/1553

${ }_{29}$ Filipenko, A.S., Budkin, V.S., \& Dudchenko, M.A. (2004). International integration processes of today: monograph. Kyiv: Znannya Ukrainy. [in Ukrainian].

${ }^{30}$ Chuzhykov, V. (2016). Regional policy of the European Union. Kyiv: Kyiv National Economic University. [in Ukrainian].

Chen, J. (2011). Factors shaping regional integration in Europe, Asia and Africa: the validity of competing theories. Alberta (Canada): University of Lethbridge.

Shnyrkov, O.I., Filipenko, A.S., Zablotska, R.O. (2016). Development of the modern forms of the international economic integration in the beginning of the $21^{s t}$ century: monograph. Kyiv: Kyiv University. [In Ukrainian].

${ }^{33}$ Hamilton-Hart N. (2003). Asia's new regionalism: government capacity and cooperation in the Western Pacific. Review of International Political Economy. Vol.10. Issue 2: 222-245.

Wahl, P. (2017). Between Eurotopia and nationalism: a third way for the future of the EU. Globalizations. Volume 14. Issue 1: 157-163.

Bowen H.P., Sleuwaegen L. (2007). European integration: the third step. International Economics and Economic Policy. Vol. 4. Issue 3: 241-262.

${ }^{4}$ Shnyrkov, O.I., Filipenko, A.S., Zablotska, R.O. (2016). Development of the modern forms of the international economic integration in the beginning of the $21^{s t}$ century: monograph. Kyiv: Kyiv University. [In Ukrainian].
} 
integration (data on them for years 2015 - 2016 are presented in the table 1); he Shanghai Cooperation Organization (SCO) is the regional association; trans-regional integration associations - Trans-Pacific Partnership (TPP), Regional Comprehensive Economic Partnership (RCEP) and Transatlantic Trade and Investment Partnership (TTIP); transcontinental associations: Asia-Pacific Economic Cooperation (APEC), BRICS. Selected regional associations form the basis of global economic system at the dawn of the XXI century.

Data of table 1 point to the fact that NAFTA is in the first place according to regional Nominal GDP in 2015 (20648136 billions of dollars); EU is in the second place (16 067 827), MERCOSUR is in the third place (3 504079 billions of dollars). NAFTA also is in the first place according to relative share of production of regional nominal GDP in global GDP in 2015 among integration associations - 27.62\%; EU is in the second place (21.49); MERCOSUR is in the third place (4.69); SAARC is in the fourth place (3.75) and ASEAN is in the fifth place (3.28); EEU is in the eighth place (2.07); ECOWAS is in the twelfth place $(0.09 \%)$.

NAFTA is in the first place among selected regional integration associations according to GDP amount per head of population in 2015 (42266,7 US dollars); GCC is in the second place (32751,5); EU is in the third place $(31686,7)$; MERCOSUR is in the fourth place $(11982,1)$; EEU is in the fifth place $(8636,2)$; AP is in the sixth place (8344,9 US dollars). ASEAN is in the eighth place (3879,5 US dollars); ECOWAS is in the tenth place (1900,8 US dollars).

SAARC (South Asian FTA - SAFTA) is in the first place according to number of inhabitants in 2016 (1766 millions of inhabitants); ASEAN is in the second place (641); EU is in the third place (510); GCC is in the last place (53 millions of inhabitants). Data on export and import of goods within 2015-- 2016 presented in table 1 point to the fact that NAFTA shows the level of stability of export and import of goods similar to EU. SAARC, AP, ACN, MERCOSUR have the best results on export of the goods in comparison with ECOWAS and ASEAN. The import of MERCOSUR was reduced substantially.

The abovementioned analysis of data points to the fact that NAFTA is the most powerful free trade area in economic terms, due to the fact that it includes the USA. EU is the most developed regional association in the context of integration processes as it has the developed supranational system of regulatory authorities, common citizenship, own currency that earned the status of world's reserve currency. EEU, the economic union, is the second according to the stage of integration. 


\begin{tabular}{|c|c|c|c|c|c|c|}
\hline \multirow{3}{*}{ 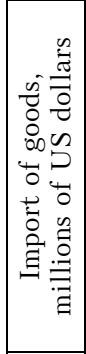 } & 류율 & $\stackrel{\infty}{\stackrel{0}{0}}$ & $\tilde{\vartheta}$ & $\stackrel{\sim}{\mathscr{S}}$ & $\begin{array}{l}\dot{0} \\
\dot{s}\end{array}$ & $\hat{\theta}$ \\
\hline & $\stackrel{\circ}{\stackrel{\sim}{\sim}}$ & 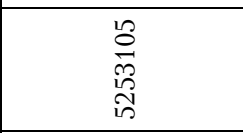 & $\stackrel{\substack{\infty \\
\infty}}{\stackrel{\infty}{\sim}}$ & 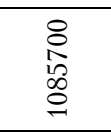 & 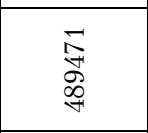 & 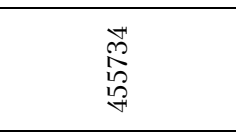 \\
\hline & $\stackrel{\stackrel{2}{5}}{\stackrel{N}{N}}$ & 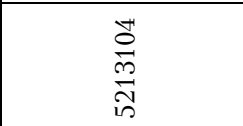 & 高 & 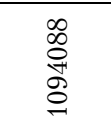 & $\underset{\stackrel{\infty}{\grave{1}}}{\stackrel{\infty}{i s}}$ & $\underset{\stackrel{\infty}{+}}{\stackrel{8}{\forall}}$ \\
\hline \multirow{3}{*}{ 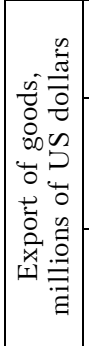 } & 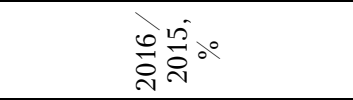 & $\begin{array}{l}\infty \\
\infty \\
\infty\end{array}$ & $\underset{\infty}{\infty}$ & $\underset{\infty}{i}$ & $\ddot{s}$ & $\overline{0}$ \\
\hline & $\stackrel{\circ}{\stackrel{\sim}{N}}$ & 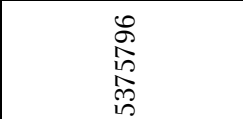 & 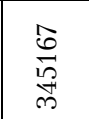 & 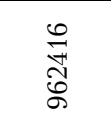 & 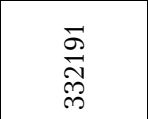 & $\begin{array}{l}\infty \\
\stackrel{h}{1} \\
\infty \\
\infty \\
i n\end{array}$ \\
\hline & $\stackrel{n}{\stackrel{2}{N}}$ & $\begin{array}{l}m \\
\substack{\infty \\
\infty \\
i n \\
i n}\end{array}$ & 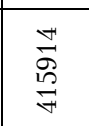 & 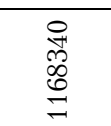 & $\underset{m}{\stackrel{m}{\#}}$ & $\stackrel{\infty}{\stackrel{\infty}{g}}$ \\
\hline \multicolumn{2}{|c|}{ 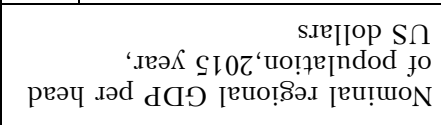 } & $\begin{array}{l}\hat{N} \\
\ddot{0} \\
\stackrel{0}{m}\end{array}$ & $\begin{array}{l}\text { } \\
\hat{\bigotimes}^{-} \\
\infty\end{array}$ & $\begin{array}{l}n \\
0 \\
0 \\
0 \\
0\end{array}$ & $\begin{array}{l}n \\
1 \\
0 \\
0 \\
0\end{array}$ & 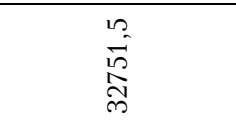 \\
\hline \multicolumn{2}{|c|}{ 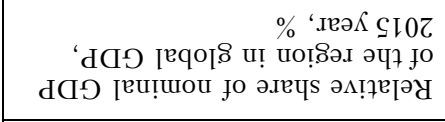 } & 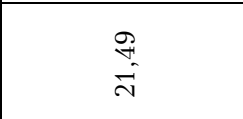 & $\hat{o}$ & $\stackrel{\infty}{\sim}$ & $\begin{array}{l}\frac{1}{12} \\
i\end{array}$ & $\bar{m}$ \\
\hline \multicolumn{2}{|r|}{ 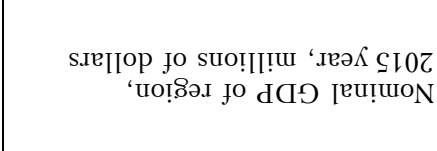 } & $\begin{array}{l}\hat{0} \\
\infty \\
\vdots \\
0 \\
0\end{array}$ & $\begin{array}{l}2 \\
13 \\
0 \\
1 \\
13 \\
10\end{array}$ & 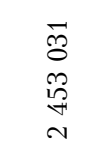 & $\begin{array}{l}n \\
\bar{\sigma} \\
\tilde{O} \\
\infty \\
\sim\end{array}$ & 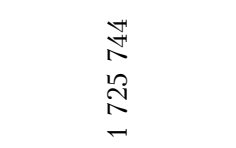 \\
\hline \multirow{2}{*}{ 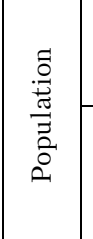 } & suos.əəd jo suo!̣!!̣ய ‘910z & 응 & $\stackrel{\infty}{\sim}$ & $\overline{8}$ & $\stackrel{\&}{\leftrightarrows}$ & is \\
\hline & $\begin{array}{r}\text { suos.əəd jo } \\
\text { spursnoy7 'c LI0Z }\end{array}$ & $\begin{array}{l}0 \\
0 \\
0 \\
10 \\
0 \\
13\end{array}$ & 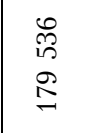 & 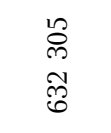 & $\begin{array}{l}\hat{\infty} \\
\infty \\
\stackrel{\circ}{+} \\
\stackrel{\sim}{\sim}\end{array}$ & $\begin{array}{l}\text { 今ి } \\
\text { ô. } \\
\text { î }\end{array}$ \\
\hline & 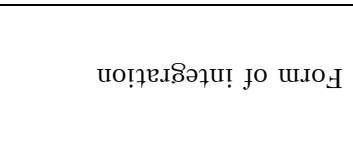 & 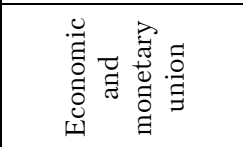 & 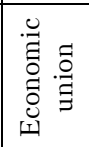 & 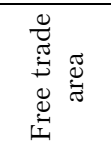 & 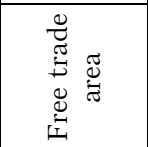 & 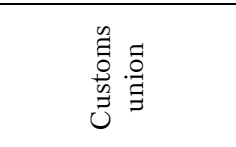 \\
\hline \multirow{2}{*}{\multicolumn{2}{|c|}{ 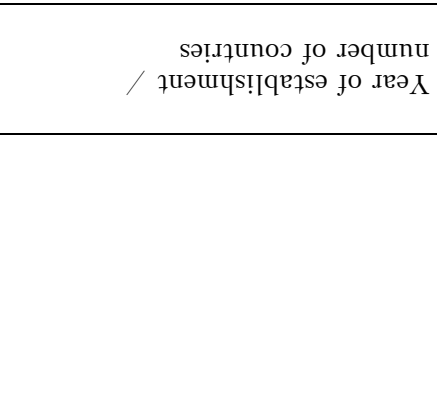 }} & 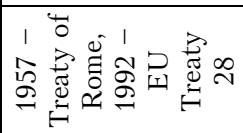 & 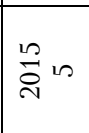 & $\stackrel{2}{\circ}$ & $\stackrel{\infty}{\circ} \infty$ & $\vec{\infty}_{\circ} 0$ \\
\hline & & 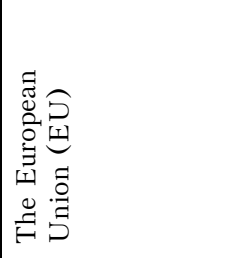 & 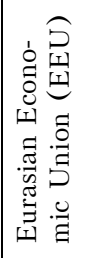 & 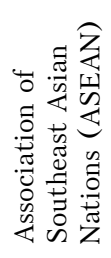 & 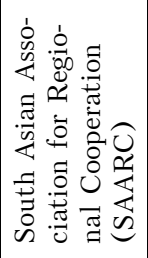 & 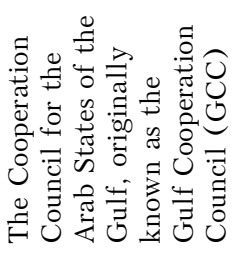 \\
\hline & $\dot{z}$ & - & $\sim$ & $m$ & $\checkmark$ & is \\
\hline
\end{tabular}




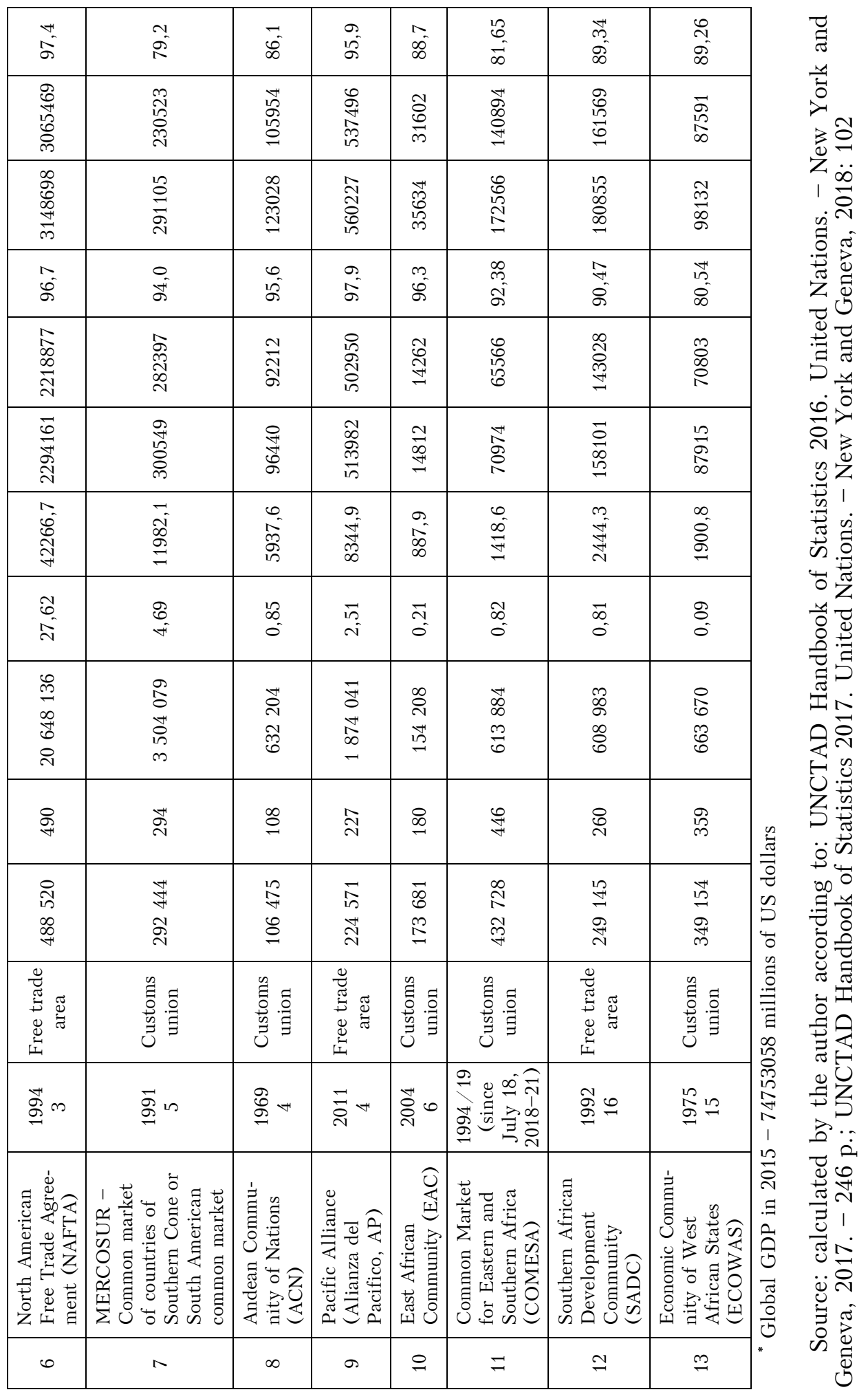


ASEAN is the most developed integration association in Asia, functioning in the form of free trade area. The analytical report to the Annual message of the President of Ukraine accentuates that the state has to strengthen its cooperation with regional organizations in Asia, in particular, with ASEAN and $\mathrm{SCO}^{1}$. There is a spread of new integration initiatives of ASEAN $(+3,+6,+8)$ involving East Asian and other pacific partners ${ }^{2}$ including China and India, SAARC functions in the form of free trade area (SAFTA) and has an intention to transform into common market of South Asia, where India plays a key role. GCC is a customs union and later it plans to strengthen the unity that will define the future of conflict and unstable Western Asia.

EAC, COMESA, SADC and ECOWAS are the main associations of Africa. The tripartite free trade area was signed in 2015 (COMESAEAC-SADC) under predicted consolidation of role of SADC in it, including the Republic of South Africa (RSA) that is a member of BRICS together with India and PRC. TRFA already covers 27 African countie $^{3}$. ACN, MERCOSUR, AP represent the processes of establishment of regional associations of Latin America. MERCOSUR is the centre of integration in Latin America. MERCOSUR implements the policy of diversification of external relations, in particular towards South-South; it resists the monopolistic domination of the USA both in the continent and across the globe, It is believed that the initiative of the USA oriented to the establishment of all-American Free Trade Area, that would like to cover 34 countries of North, Central and South America, the negotiations towards which lasted within years 1994 2005, failed precisely due to activity of MERCOSUR ${ }^{4}$. MERCOSUR presents itself as one of the prospective poles of international economic and political influence at worldwide level.

So, the data in table 1 show the leadership of associations NAFTA and EU. EU and EEU, being rather weaker, achieved the form of economic union and established the supranational authorities; the rest of associations function in the form of free trade area and customs union. ASEAN, SAARC and MERCOSUR facilitate the consolidation of role of China, India and Brazil in Asia and Latin America.

SCO plays a special part among regional associations (table 2).

\footnotetext{
${ }^{1}$ Analytical report to the Annual Message of the President of Ukraine to the Parliament of Ukraine «On the internal and external state of Ukraine in 2017». Kyiv: National Institute for Strategic Studies, 2017. [in Ukrainian].

${ }^{2}$ Sardak, S.E. (2016). The potential of economic development of ASEAN. Eastern Europe: economy, business and management. Vol.5(05): 41-44. [In Ukrainian].

SADC-EAC-COMESA Tripartite Free Trade Area. Legal texts and policy documents / Tralac trade law centre. Available at: www.tralac.org

${ }_{4}^{4}$ Smoliy, A.V. (2016). Development of the Latin-American customs unions at the modern stage. Scientific Bulletin of Uzhhorod National University. Series: Law Studies. Vol. 40, Issue 2: 153-157. [In Ukrainian].
} 
Table 2 Macroeconomic Indicators Of Development Of Countries SCO Members, Years 2015-2016

\begin{tabular}{|c|c|c|c|c|c|c|c|c|c|}
\hline & 节 & 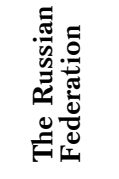 & 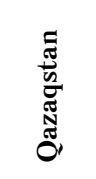 & 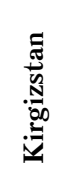 & 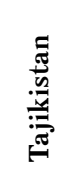 & 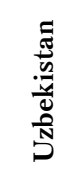 & 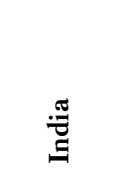 & 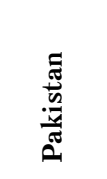 & 焉 \\
\hline $\begin{array}{l}\text { Population } \\
\text { thou-sands } \\
\text { persons } \\
2016 \text { of millions of } \\
\text { persons }\end{array}$ & $\begin{array}{c}1376049 \\
1404\end{array}$ & $\begin{array}{c}143457 \\
144\end{array}$ & $\begin{array}{c}17625 \\
18\end{array}$ & $\begin{array}{c}5940 \\
6\end{array}$ & $\begin{array}{c}8482 \\
9\end{array}$ & $\begin{array}{c}29893 \\
31\end{array}$ & $\begin{array}{c}1311051 \\
1324\end{array}$ & $\begin{array}{c}188925 \\
193\end{array}$ & $\begin{array}{c}3081422 \\
3129\end{array}$ \\
\hline $\begin{array}{l}\text { Nominal } \\
\text { millions of } \\
\text { dollars } \\
2015 \\
2016\end{array}$ & $\begin{array}{c}11156254 \\
-\end{array}$ & $\begin{array}{c}1296265 \\
-\end{array}$ & $\begin{array}{c}183931 \\
-\end{array}$ & $\begin{array}{c}6793 \\
-\end{array}$ & $\begin{array}{c}8814 \\
-\end{array}$ & $\begin{array}{c}65853 \\
-\end{array}$ & $\begin{array}{c}2219669 \\
-\end{array}$ & $\begin{array}{c}266383 \\
-\end{array}$ & $\begin{array}{c}15203962 \\
-\end{array}$ \\
\hline $\begin{array}{l}\text { GDP per head of } \\
\text { population, US } \\
\text { dollars } \\
2015 \\
2016\end{array}$ & $\begin{array}{l}8107 \\
8110\end{array}$ & $\begin{array}{l}9036 \\
8916\end{array}$ & $\begin{array}{c}10436 \\
7520\end{array}$ & $\begin{array}{l}1144 \\
1024\end{array}$ & $\begin{array}{c}1039 \\
813\end{array}$ & $\begin{array}{l}2203 \\
2271\end{array}$ & $\begin{array}{l}1693 \\
1718\end{array}$ & $\begin{array}{l}1410 \\
1478\end{array}$ & $\begin{array}{c}4934,1 \\
-\end{array}$ \\
\hline $\begin{array}{l}\text { Export of goods, } \\
\text { millions of } \\
\text { dollars } \\
2015 \\
2016\end{array}$ & $\begin{array}{l}2274949 \\
2097632\end{array}$ & $\begin{array}{l}340349 \\
281681\end{array}$ & $\begin{array}{l}45726 \\
36775\end{array}$ & $\begin{array}{l}1676 \\
1503\end{array}$ & $\begin{array}{l}891 \\
977\end{array}$ & $\begin{array}{l}12304 \\
10000\end{array}$ & $\begin{array}{l}267147 \\
264402\end{array}$ & $\begin{array}{l}22188 \\
20435\end{array}$ & $\begin{array}{l}2965230 \\
2713405\end{array}$ \\
\hline $\begin{array}{l}\text { Import of goods, } \\
\text { millions of } \\
\text { dollars } \\
2015 \\
2016\end{array}$ & $\begin{array}{l}1681951 \\
1587925\end{array}$ & $\begin{array}{l}194087 \\
191672\end{array}$ & $\begin{array}{l}30186 \\
25377\end{array}$ & $\begin{array}{l}4070 \\
3963\end{array}$ & $\begin{array}{l}3885 \\
4297\end{array}$ & $\begin{array}{l}10264 \\
11500\end{array}$ & $\begin{array}{l}391977 \\
359774\end{array}$ & $\begin{array}{l}44219 \\
47155\end{array}$ & $\begin{array}{l}2360639 \\
2231663\end{array}$ \\
\hline
\end{tabular}

Source: calculated by the author according to UNCTAD Handbook of Statistics $2016-2017$

SCO is a regional intergovernmental organization established in 2001 Shanghai by the leaders of Qazaqstan, PRC, the Kyrgyz Republic, RF, Tajikistan and Uzbekistan; India and Pakistan joined in 2016. Intentions of the organization to strengthen the economic component of its activity and availability of PRC, India, RF and Pakistan in their composition enable it to form the model of the future cooperation of countries of various civilizations.

\footnotetext{
${ }^{5}$ The Shanghai Cooperation Organization. Available at: http://eng.sectsco.org
} 


\section{From regional associations to trans-regional alliances}

At the end of XX century - at the dawn of the XXI century new large trans-regional alliances TPP, Council of Mutual Economic Assistance and T-TIP get the names of partnerships. Economic partnerships may be designated as the first integration stage, including the elements of the third stage - creation of zones regulated according to common rules of movement of goods, services, partially capitals, primarily - investments. The partnerships do not set a goal to create the customs union, i.e. to implement the unified customs policy concerning third countries, enabling third countries to establish relations of various levels and various formats with certain members of the partnerships ${ }^{6}$. Negotiations on the establishment of TPP started in 2006. However, it became greatly important for global trading system in 2008 when the USA joined in the negotiation process ${ }^{7}$. The negotiation process on coordination of provisions of TPP between 12 countries was completed in Alanta in October 2015. China was not included into this partnership. $42 \%$ from global GDP accounts for TPP according to nominal exchange rate (and 28\% from global GDP accounts for purchasing power parity), 23\% from world export of goods, $25 \%$ from world export of services and 33\% from world

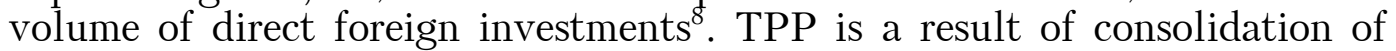
leadership of the USA in APR. Due to the fact that the continental land mass of Eastern Asia is under the control of PRC. The USA and Japan prioritize over empowerment of naval capacity 9 . Struggle between the USA and PRC started in APR. At the same time, Japan, EU and BRICS try to implement their interests.

Council of Mutual Economic Assistance have to be considered, firstly, as a special compromise between EAFTA (East Asian Free trade area) and CEPEA (Comprehensive Economic Partnership for East Asia), and, secondly, as an alternative of TPP, that includes not all members of ASEAN, and, thirdly, as a mean of maintenance of ASEAN in the role of driving force of regional integration processes. $70 \%$ from all free trade agreements in Asia account for countries of the Council of Mutual Economic Assistance. Considering that the area of the Council of Mutual Economic Assistance may cover the countries of the world, where almost half of the population lives (over 3 billions of persons), $33 \%$ from global GDP is produced and around $40 \%$ from world trading

\footnotetext{
${ }^{6}$ Kheyfets, B. (2016). Transregional reformatting of the global economic space. Moscow: The Institute of Economy, Russian Academy of Sciences. [In Russian].

Us, I.V. On peculiarities of the foreign economic policy of Ukraine in the conditions of creation of new integration mega-blocks. Analytical notes. Available at: http://www.niss.gov.ua/articles/1553

Kheyfets, B. (2016). Transregional reformatting of the global economic space. Moscow: The Institute of Economy, Russian Academy of Sciences. [In Russian].

${ }_{9}$ Shergin, S.O. (2015). Dilemma of Asia-Pacific regionalism. Scientific Bulletin of the Diplomatic academy of Ukraine. Vol. 22(2): 36-49.
} 
is realized, the Council of Mutual Economic Assistance is expected to become the largest integration grouping in the world ${ }^{10}$. Comparison of the Council of Mutual Economic Assistance and TPP according to various parameters is presented in the table 3 .

\section{Table 3 Key Macroeconomic Indicators Of The Council}

\section{Of Mutual Economic Assistance And TPP, Years 2014-2015 ${ }^{11}$}

\begin{tabular}{|c|c|c|}
\hline Characteristic & $\begin{array}{l}\text { The Council of Mutual Economic } \\
\text { Assistance }\end{array}$ & TPP \\
\hline Signing of an agreement & $\begin{array}{l}\text { September 2016, signing of the free trade } \\
\text { agreement is scheduled for November } 2018\end{array}$ & February 2016 \\
\hline $\begin{array}{l}\text { Population, millions of } \\
\text { persons, 2014 }\end{array}$ & 3461 & 809 \\
\hline $\begin{array}{l}\text { Volume of nominal GDP, } \\
\text { billions of dollars, } 2014\end{array}$ & 22658 & 28031 \\
\hline $\begin{array}{l}\text { Export of goods and } \\
\text { services, billions of dollars, } \\
2014\end{array}$ & 6419 & 5608 \\
\hline $\begin{array}{l}\text { Number of member countries } \\
\text { (2016) }\end{array}$ & 16 & 12 \\
\hline $\begin{array}{l}\text { Official initial goals of } \\
\text { project }\end{array}$ & $\begin{array}{l}\text { Implementation of concept of multilateral } \\
\text { free trade area ASEAN }\end{array}$ & $\begin{array}{l}\text { Creation of new } \\
\text { trade model of } \\
\text { XXI century }\end{array}$ \\
\hline Membership model & $\begin{array}{l}\text { Model «ASEAN plus X» accession of other } \\
\text { countries is accepted }\end{array}$ & $\begin{array}{c}\text { Model «All } \\
\text { APR countries» }\end{array}$ \\
\hline $\begin{array}{l}\text { Number of available mutual } \\
\text { regional trade deals (2015) }\end{array}$ & $>40$ & $>55$ \\
\hline $\begin{array}{l}\text { Share of mutual export in } \\
\text { the total export, } \%, 2014\end{array}$ & 41 & 48 \\
\hline Main drivers & ASEAN and China & the USA \\
\hline $\begin{array}{l}\text { Connection with the } \\
\text { existing regional institutes }\end{array}$ & $\begin{array}{l}\text { It is established according to the principles } \\
\text { of cooperation in ASEAN }\end{array}$ & $\begin{array}{l}\text { Is not related to } \\
\text { any existing } \\
\text { organization }\end{array}$ \\
\hline Common members & \multicolumn{2}{|c|}{$\begin{array}{c}\text { Australia, Brunei, Japan, Malaysia, New Zealand, Singapore, } \\
\text { Vietnam }\end{array}$} \\
\hline Important absent members & the USA & $\begin{array}{c}\text { China, } \\
\text { Indonesia, } \\
\text { South Korea }\end{array}$ \\
\hline Zeroing of trade restrictions & Around $90 \%$ of rates & $\begin{array}{l}\text { Around } 99 \% \text { of } \\
\text { rates }\end{array}$ \\
\hline
\end{tabular}

10 Shnyrkov, O.I., Filipenko, A.S., Zablotska, R.O. (2016). Development of the modern forms of the international economic integration in the beginning of the $21^{\text {st }}$ century: monograph. Kyiv: Kyiv University. [In Ukrainian].

${ }^{11}$ Kheyfets, B. (2016). Transregional reformatting of the global economic space. Moscow: The Institute of Economy, Russian Academy of Sciences. [In Russian]. 
T-TIP provides for establishment of free trade area, combining the most powerful country, the USA, and the most-developed association, EU, for the purpose of consolidation and expansion of leadership of Occidental civilization. So, TPP and T-TIP are aimed at consolidation of role of the USA, the Council of Mutual Economic Assistance - PRC. However, it is too soon to claim the hegemonial decline of the USA until mid-twenty-first century, due to the fact that China does not have precedence over the USA according to any measurement of hegemony: military, economic, political, institutional, ideological ${ }^{12}$.

Regional associations of Asia located in APR play a special part among regional associations of Asia. APR became the third largest centre of economic integration in XXI century, which regionalism acquired global value ${ }^{13}$. APR as the geopolitical and geo-economical space for a long historical period remained on the margins of main trends of global changes. However, the very collapse of bipolar system in the 1990s of XX century caused the emergence of new centre of international economic cooperation that became the scene of interstate and civilizational discords ${ }^{14}$. It is APR where APEC was established, the world's largest organization according to space and volume of resources $^{15}$. APEC is formed by the countries of Eurasia (Russia), Asia (Brunei, Vietnam, Indonesia, China, Republic of Korea, Malavsia, Singapore, Thailand, Philippines, Japan), Northern (USA, Canada, Mexico) and South America (Peru, Chile), Australia, New Zealand and Papua New Guinea, that is 19 countries across four continents, and the territories Hong Kong and Taiwan.. APEC may be conditionally (due to absence of status of free trade area) considered to be the world's fist trans-continental cooperation, established in 1989 in Canberra upon an initiative of Australia and New Zealand. Main indicators are presented in the table 4.

BRICS is a dialogue mean; India and $\mathrm{PRC}^{16}$ perform central functions; Brazil and China are the key centres of trade: volumes of export and import considerably exceed the volumes in the other countries; share of Brazil in goods turnover is equal to $19.2 \%$, and the

\footnotetext{
12 Puriy, M.R. (2017). Hegemony in theory and practice of international relations: abstract of dissertation for $\mathrm{PhD}$ in Political Sciences. Chernivtsi: Chernivtsi National University named after Yuriy Fed'kovych. [in Ukrainian].

${ }^{13}$ Marynina, S.V. (2013). The peculiarities of the integration development in the Asia-Pacific region. The Economic annals XXI. Vol. №1-2(2): 3-6. [In Ukrainian].

${ }^{14}$ Korinets, G.B., Fleychuk, M.I., \& L'vivska, K.A. (2011). The importance of Ukrainian-Asian relations in the conditions of strengthening globalization processes. Bulletin of the National Lisotechnichny University of Ukraine. Vol. 21.9: 367-372. [in Ukrainian].

15 Asia-Pacific Economic Cooperation. Key indicators database. StatsAPEC: http://statistics.apec.org/index.php/apec_psu/index_noflash world economy. Mukachiv State University. Vol.4: 55-61. [In Ukrainian].
} 
share of China is equal to $38.2 \%^{17}$. Close cooperation between Brazil and RF, PRC, India and RSA enables to balance trade and economic exchanges and to cooperate in strategic and defense sphere etc ${ }^{18}$. Specific character of BRICS lies in the fact that the countries present five local civilizations - Latin-American, Orthodox and Slavonic, Indian, Chinese and African. Characteristic of BRICS countries is presented in table 5.

\section{Table 4 Key Macroeconomic Indicators Of APEC, Years $2012-2^{2016}$}

\begin{tabular}{|l|c|c|c|c|c|}
\hline \multicolumn{1}{|c|}{ Indicator } & $\mathbf{2 0 1 2}$ & $\mathbf{2 0 1 3}$ & $\mathbf{2 0 1 4}$ & $\mathbf{2 0 1 5}$ & $\mathbf{2 0 1 6}$ \\
\hline $\begin{array}{l}\text { GDP, millions of } \\
\text { dollars }\end{array}$ & $42,614,873.2$ & $43,555,316.2$ & $44,683,187.4$ & $44,076,701.0$ & $45,108,718.2$ \\
\hline $\begin{array}{l}\text { GDP per head of } \\
\text { population, dollars }\end{array}$ & $15,268.4$ & $15,498.5$ & $15,789.7$ & $15,512.7$ & $15,767.9$ \\
\hline $\begin{array}{l}\text { Total number of } \\
\text { inhabitants, } \\
\text { thousands of persons }\end{array}$ & $2,791,049.3$ & $2,810,297.8$ & $2,829,889.1$ & $2,849,246.9$ & $2,868,871.1$ \\
\hline $\begin{array}{l}\text { Level of } \\
\text { unemployment, \% }\end{array}$ & 4.9 & 4.9 & 4.7 & 4.6 & 4.5 \\
\hline $\begin{array}{l}\text { Import of goods and } \\
\text { services, millions of } \\
\text { dollars }\end{array}$ & $10,960,253.9$ & $11,210,513.6$ & $11,386,484.6$ & $10,243,030.2$ & $9,965,854.8$ \\
\hline $\begin{array}{l}\text { Export of goods and } \\
\text { services, millions of } \\
\text { dollars }\end{array}$ & $10,478,415.8$ & $10,757,886.5$ & $11,043,154.1$ & $10,205,880.6$ & $9,882,769.9$ \\
\hline
\end{tabular}

Table 5 Key Macroeconomic Indicators Of BRICS ${ }^{20}$

\begin{tabular}{|l|c|c|c|c|c|c|}
\hline & Brazil & $\begin{array}{c}\text { The Russian } \\
\text { Federation }\end{array}$ & India & China & RSA & Total \\
\hline $\begin{array}{l}\text { Population } \\
\text { 2015, thousands of persons }\end{array}$ & $\begin{array}{c}207848 \\
2016, \text { millions of persons }\end{array}$ & $\begin{array}{c}143457 \\
144\end{array}$ & $\begin{array}{c}1311051 \\
1324\end{array}$ & $\begin{array}{c}1376049 \\
1404\end{array}$ & $\begin{array}{c}54490 \\
56\end{array}$ & $\begin{array}{c}3092895 \\
3136\end{array}$ \\
\hline $\begin{array}{l}\text { Nominal GDP, millions of } \\
\text { US dollars }\end{array}$ & 1739955 & $\begin{array}{c}1296265 \\
2015\end{array}$ & - & 2219669 & 11156254 & 314980 \\
2016 & - & - & - & - & 16727123 \\
\hline
\end{tabular}

${ }^{17}$ Karabaza, I.A., \& Klipo, M.S. (2017). The development tendencies of the BRICS countries and their influence on the modern international economic relations. Prychornomorsky economic studios. Vol. 15: 6-9. [in Ukrainian].

${ }^{18}$ Bessarab, T., \& Tsybukh, I. (2017). Development, peculiarities of partnership and importance of Brazil's membership in BRICS. Bulletin of the National University «Lviv Politechnics». Political sciences. Vol.3, Issue 1: 16. [In Ukrainian].

${ }_{19}$ StatsAPEC, Key indicators database: http://statistics.apec.org/index.php/apec psu/index noflash

20 calculated by the author according to data UNCTAD Handbook of Statistics 2016-2017 


\begin{tabular}{|l|c|c|c|c|c|c|}
\hline & Brazil & $\begin{array}{c}\text { The Russian } \\
\text { Federation }\end{array}$ & India & China & RSA & Total \\
\hline $\begin{array}{l}\text { GDP per head of popula- } \\
\text { tion, US dollars }\end{array}$ & & & & & & \\
2015 & 8371 & 9036 & 1693 & 8107 & 5780 & 5408,2 \\
2016 & 8532 & 8916 & 1718 & 8110 & 5210 & - \\
\hline $\begin{array}{l}\text { Export of goods, millions of } \\
\text { US dollars }\end{array}$ & & & & & \\
2015 & 191134 & 340349 & 267147 & 2274949 & 81673 & 3155252 \\
2016 & 185280 & 281681 & 264402 & 2097632 & 75091 & 2904086 \\
\hline $\begin{array}{l}\text { Import of goods, millions of } \\
\text { US dollars }\end{array}$ & & & & & & \\
2015 & 178798 & 194087 & 391977 & 1681951 & 90357 & 2537170 \\
2016 & 143474 & 191672 & 359774 & 1587925 & 91580 & 2374425 \\
\hline
\end{tabular}

Let's summarize that if in the 1940s of XX century the USA started to consolidate its position on the global stage by the implementation of integration processes in Europe (on the basis of the «Marshall Plan»), as well as by the establishment of international institutions, then at the dawn of XXI century strengthening of its power is facilitated by the initiatives of TPP, T-TIP and APEC, where the USA plays a key role, using its influence on the formation of not only trade policy, but also a solution of the wide range of problems both within Euro-Atlantic and global space. At the same time, the development of trans-regional integration association, the Council of Mutual Economic Assistance, regional organization SCO and trans-continental BRICS give evidence of increasingly larger role in the global economy of China, India that facilitate the establishment of new centre of economic development of the world, being competitive in relation to the USA, that finds its institutionalization in the formation of association BRICS.

\section{Prospects of regionalization of global economy}

Free trade areas and customs unions are the basic forms of integration associations; interrelations between them develop in trade relations, influenced by the USA, PRC and EU. The export of goods in millions of US dollars and its percent from global export was equal respectively in 2016: for PRC - 2096 and 16.8; for EU - 1932 and 15.4; for the USA 1455 and $11.6^{21}$. So, 58\% from global trade, 56\% from global export, $60 \%$ from global import and 53\% from global GDP and the market volume equal to 1.6 billions of consumers accounted for EU, NAFTA and ASEAN in $2016^{22}$.

\footnotetext{
${ }_{21}^{21}$ World trade statistical review 2017. - Geneva: World trade organization, 2018. - P. 103.

${ }^{22}$ World trade statistical review 2017. - Geneva: World trade organization, 2018. — P. 50.
} 
Table 6 Relative Share Of Export Of Goods Of Regional Associations On Continents In Total Export In 2015, \%

\begin{tabular}{|l|c|c|c|c|c|c|}
\hline & Europe & Asia & $\begin{array}{c}\text { North } \\
\text { America }\end{array}$ & $\begin{array}{c}\text { Central and South } \\
\text { America, the } \\
\text { Caribbean }\end{array}$ & Africa & Other \\
\hline EU & 69,5 & 10,2 & 9,0 & 1,7 & 3,1 & 6,5 \\
\hline NAFTA & 15,6 & 20,4 & 50,0 & 7,7 & 1,4 & 4,9 \\
\hline MERCOSUR & 18,0 & 28,3 & 20,4 & 21,8 & 4,2 & 7,3 \\
\hline ASEAN & 12,1 & 66,9 & 12,2 & 1,9 & 2,3 & 4,6 \\
\hline ECOWAS & 39,8 & 21,6 & 5,3 & 5,7 & 24,2 & 3,4 \\
\hline
\end{tabular}

Data in the table 6 also show the influence of main regional associations on world trade processes. EU exports the largest part of its products to European countries caused by the development of internal trade within its bounds that, in turn, is caused by high level of mutual dependence of the countries forming it. This regularity of relations is confirmed by: NAFTA (50.5\% from export is oriented to North America), ASEAN (66.9\% from export is oriented to the countries of Asia).

Special attention shall be given to interrelations between the USA and EU as two of three centres of economic development of the world (table 7).

\section{Table 7 Dynamics Of Bilateral Trade In Goods Of EU -} The USA In Years 2012 - 2014, Billions Of Euro ${ }^{24}$

\begin{tabular}{|c|c|c|c|}
\hline Year & EU import & EU export & Balance \\
\hline 2012 & 206,5 & 293,2 & 86,7 \\
\hline 2013 & 196,2 & 289,5 & 93,3 \\
\hline 2014 & 204,9 & 310,9 & 106,0 \\
\hline
\end{tabular}

Interest in strengthening of economic relations with EU is shown by the countries and their regional associations, located almost in all continents of the world that is evidenced by the great number of existing (over 40 already signed) and executed regional trade deals, as well as the draft agreement of T-TIP, the implementation of which will introduce the amendments to the system of international economic relations.

\footnotetext{
${ }^{23}$ World trade statistical review 2017. - Geneva: World trade organization, 2017. - P. 52

${ }^{24}$ Shnyrkov, O.I., Filipenko, A.S., Zablotska, R.O. (2016). Development of the modern forms of the international economic integration in the beginning of the $21^{s t}$ century: monograph. Kyiv: Kyiv University. [In Ukrainian].
} 
The development of integration processes between EU and the countries of Latin America is formed as controversy concerning the influence of the USA on this region. MERCOSUR signed a variety of agreements, including the agreement on economic complementarity signed with Cuba in 2006; the agreements oriented to liberalization of the trade signed with India, Pakistan, RSA and Egypt; the agreement on free trade area signed with Israel in 2007. Negotiations on closer foreign trade relations with Canada, Australia, New Zealand and Japan are conducted. The framework agreement on cooperation with EU was concluded in Madrid in 1995 that provided for the establishment of intercontinental free trade area between two integration blocs - EU and MERCOSUR; the negotiations on the EU partnership agreement were resumed in 2010 after six-year break; the negotiations with EU concerning establishment of free trade areas were renewed in 2017. Brisk growth of relations between EU and the countries of Latin America conflicts with the interests of the USA that may be magnified by the fact that Brazil is a member of BRICS. The framework agreement with ACN came into effect in 2004; the agreement on cooperation with GCC was signed in $2005^{25}$. The agreement on the establishment of free trade area with UAE was concluded; cooperation with African countries is increased; these countries are considered as the prospective market for promotion of Brazilian technologies and goods; trade and economic relations with PRC develop.

EU has a significant influence on African continent ${ }^{26}: 1 / 3(35.2 \%)$ of the foreign trade turnover of Africa accounts for EU in 2016. Share of China as the second trade partner of Africa is equal to $15 \%$, and as the third trade partner of India is equal to $7 \%$. So, RSA exports to EU $20 \%$ from all export, Algeria - 14, Morocco - 12, Nigeria - 9, Tunisia -8 , Egypt $-6 \%$. There has been observed the increase in role of Africa in the provision of development of EU that plans to invest 40 billions of euro into the development of the continent within years 2014 2020. The volume of national assistance of EU to Africa was equal to 141 billions of euro within years 2007 - 2013. It should be noted that Germany announced an initiative «Compact with Africa», the implementation of which will strengthen links between countries of EU and Africa ${ }^{27}$. PRC also influences on the integration processes in Africa: PRC and 49 countries of Africa participate in China - Africa

\footnotetext{
${ }^{25}$ Smoliy, A.V. (2016). Development of the Latin-American customs unions at the modern stage. Scientific Bulletin of Uzhhorod National University. Series: Law Studies. Vol. 40, Issue 2: 153-157. [In Ukrainian].

Lileyev, I.L. (2015). EU and Africa: time to change priorities. Asia and Africa today. Vol.4: 7-10. [in Russian].

${ }^{27}$ Aleshin, K. (2018). The African vector of the European Union foreign policy: past and present. Asia and Africa today. Vol. № 3:28-31.
} 
Cooperation Forum ${ }^{28}$. The USA also strengthens the links with Africa by implementation of such form of cooperation as «USA - Africa» summit. China is a main competitor for EU in Africa. So, if the volume of trade of PRC with Africa was equal to $\$ 10$ billions in 2000, and the USA - $\$ 38.6$ billions, then it was equal to $\$ 210$ billions and $\$ 85.3$ billions $^{29}$ in 2013 respectively. Later the increase in activity of the USA will escalate the struggle for Africa between PRC, Japan, India and EU; we believe, that EU, PRC and the USA will be the primary players in this struggle.

So, the conflict of interests arises between EU and the USA both in Latin America where it is demonstrated in their relations with association MERCOSUR and in Africa, where the USA tries to consolidate its position, that may result in reduction of the influence of EU on Africa under the conditions of strengthening of penetration into the continent by China. The attention also shall be given to the Global strategy of EU oriented to creation and support of stability of states and societies both in Europe and around $\mathrm{it}^{30}$ the purpose of which is a strengthening of influence of EU beyond its borders. Development of relations of EU with $\mathrm{PRC}$ in the context of implementation of project «One belt, one road» may be considered as such that will deemphasize the T-TIP project.

China that set a goal of external policy to achieve the status of supernation until mid-twenty-first century uses the strengthening of trade relations with all countries of the world, in particular, by implementation of free trade area and increase in the volume of investments that is demonstrated clearly both in its Eurasian policy and in the implementation of the Concept «One belt, one road». So, China is a competitor of the USA; actually, China strengthens the orientation of its political and economic activity to the transformation of the existing unipolar world headed by the USA into multipolar world under the slogan of open peaceful policy ${ }^{31}$. So, probably, in perspective EU will switch between the USA and PRC, MERCOSUR (Brazil) and RF, between the USA and BRICS that is confirmed by placement of forces of key countries at worldwide level: Top-10 according to GDP in 2017 the USA (19284.99 billions of US dollars), China (12263,43), Japan $(4513,75)$, Germany $(3591,69)$, the Great Britain $(2885,48)$, France

\footnotetext{
${ }^{28}$ Mardashev, A.A. (2012). China's support to the African countries. Bulletin of Moscow State Institute for International Relations. Vol. 2(23): 59-69. [In Russian].

${ }^{29}$ Urnov, A.Yu. (2015). Summit USA-Africa. Asia and Africa today. Vol.1:2-7. [In Russian].

${ }^{30}$ Mogherini F. Foreword. Global Strategy of the European Union on the foreign policy and security policy. Available at: http://eeas.europa.eu

${ }^{1}$ Radziyevska S., Us I., Pokryshka D. (2017). Global dominates of China's development. International Economic Policy. № 26: 134-163
} 
(2537,92), India $(2487,94)$, Italy $(1901,67)$, Brazil $(1556,44)$, Canada (1530,7 billions of US dollars $)^{32}$.

EU is the main foreign trade partner of EEU in the past and in the present; China is in the second place; CIS countries are in the third place. The prospects of development of SCO are closely related to the implementation of projects «One belt - one road» and «Greater Eurasia» initiated by PRC and RF.

The Council of Mutual Economic Assistance is based on the principles of cooperation in ASEAN, being the core of regional integration in Asia, and substantially influences on world political and defensive and financial and economic processes ${ }^{33}$. ASEAN strengthens relations with China and India. ASEAN is not only the centre of cooperation in APR, but also is a key element of broad network of institutional cooperation within the region due to the range of new initiatives, structural formations, forums of various formats ${ }^{34}$ etc. that has a great potential of economic development ${ }^{35}$. The aggravation of competition between regional associations is observed in South and Eastern Asia; these associations are supported by such countries as the USA, Japan, China, Brazil and Russia. Studying the integration processes in Western Asia, in the Middle East, in the North Africa, in particular, the integration initiative in the region of Middle East and North Africa - Greater Arab FTA - GAFTA ${ }^{36}$, it is not difficult to identify the availability of the source of future competitive collisions of regional associations being which the interests of key countries and their associations are; the main of them are the USA, China, EU and the associations of Latin America.

So, there has been observed the competitive struggle between the USA, PRC and EU for the influence and subordination of regional associations of Asia, Latin America and Africa to their interests. So, the provision of primary actors of global economy with raw materials and sales markets for their products shall be considered to be the reason of this struggle. This may explain the fact that the most common form of established integration associations is free trade area, customs union and slight development of production integration that is demonstrated only in the intentions of operating associations to create common markets and

\footnotetext{
${ }^{32}$ Khalina, O.V. (2018). Unevenness of economic development of the world countries as the main problem of today. Businessinform. Vol 5: 15-20.

Analytical report to the Annual Message of the President of Ukraine to the Parliament of Ukraine «On the internal and external state of Ukraine in 2017». Kyiv: National Institute for Strategic Studies, 2017. [in Ukrainian].

${ }^{34}$ Ivasechko, O. (2015). ASEAN and the EU in comparison: geoeconomical and institutional aspects Bulletin of the National University «Lviv Politechnics». Political sciences. Vol.1, Issue 2: 27-32. [in Ukrainian].

${ }^{5}$ Sardak, S.E. (2016). The potential of economic development of ASEAN. Eastern Europe: economy, business and management. Vol.5(05): 41-44. [In Ukrainian].

${ }^{36}$ Reznikova, N.V., Ivaschenko, O.A. (2016). Development of trade liberalization in the countries of periphery: prospects for economic integration of Jordan. Economy and state. Vol.11: 19-24.
} 
to ensure further development of integration until the moment of establishment of economic union and complete integration.

Let's consider the prospects of regionalization of global economy that may lead both to the establishment of unified planetary economic system and to the formation of blocs of states and their associations that will unleash trade and hybrid wars.

Research of processes of regionalization of global economy points to the fact that they improve the productivity of social labour and at the same time exacerbate the problem of equitable distribution of its results between members of society. The law of redistribution of limited global resources in favor of the most powerful actors of global economy in economic terms and the law of maintenance of competitive strengths by them remain in force along with the law of international distribution of labour. The force of this law is confirmed by the analysis of the processes of the establishment and functioning of regional associations of global economy performed above. The processes of regionalization that grow in intensity in the global economy were initiated by the USA in their national interests. However, the countries from socialist camp were regarded as competitors to the USA for a long period, and the loss of cold war by these countries enabled the USA to promote its influence and to facilitate the expansion of processes of regionalization that took place in the camp of capitalism countries all over the world. So it is mistake to believe that the initiator and the most powerful country in the world that controls the course of regional processes will refuse from regulation of these processes voluntarily.

The analysis of regional associations performed by us enabled us to come to the conclusion that NAFTA is the most powerful in the economic terms among the world associations; EU confidently holds the second place. In addition, NAFTA may be considered as the USA strengthened due to integration with Canada and Mexico, while EU owes its establishment and success to the USA. The USA was a country that was one of the originators of modern regionalization and its development, and remains the same at the end of the 20th century. - at the dawn of the XXI century. However, as a result of processes of regionalization in the global economy, the process of establishment of associations of countries capable of concluding a block whose economic capacities will be equal to the capacities of the USA and the EU and become a competitor is actively developing. It is possible to predict the overgrowth of this economic competition between countries and their coalitions in the struggle for global resources (for the redistribution of the world), in traditional and non-traditional direct local and global collisions, trade and hybrid wars. There is a need for social consolidation as a unity of society on the basis of common goals and values; the ideological component is maximally involved in a productive 
social consolidation, which makes it not formal or coincidental, but deep and strategic ${ }^{37}$.

It is important to realize that the main contradiction consists in the desire of all to achieve a high standard of living under the conditions of limited resources, that is, the contradiction that has always led to conflicts in human society. The only solution to this is the spiritual growth of mankind and the formation of regional associations of all existing civilizations, taking into account their value orientations, and the formation of a system of consensus regulation of the global economy on their basis capable of ensuring the sustainable, equitable use of global resources of the planet Earth and the Space for the benefit all mankind, taking into account its spiritual and moral principles, and not only the selected and oriented exclusively on material goods.

\section{Conclusion}

1. Regionalization of the world economy as the formation of blocks of national states in one form or another has always been inherent in mankind, especially since the establishment of the institution of the national state. It acquired extraordinary urgency after the end of the Second World War. Activation of integration in post-war Europe is related to the «Marshall Plan», on the basis of which the USA helped the countries of Europe to rebuild a war-torn economy and in the course of implementation of which the interaction of European states with each other and with the USA intensified. The processes of regionalization in the block of socialist countries were developed through the establishment of the Council of Mutual Economic Assistance.

2. Theoretical fundamentals of the development of integration processes developed in capitalist countries before the collapse of the socialist system. This is explained by the fact that the socialist countries have developed on the basis of a planned economic system, while capitalist ones are based on a market economy. The collapse of the socialist system and the transition of the countries that formed it into a market economy made it possible to implement the regionalization processes (according to the methodology developed in the capitalist countries) in all countries of the world.

3 . The initiative measures of the USA are at the center of all of the above-mentioned processes. An important factor in accelerating the development of the processes of the establishment of regional integration associations was the worldwide national liberation movement of the

\footnotetext{
${ }^{37}$ Pyrozhkov, S.I., Khamitov, N.V., (2017). Ukrainian society on its way to consolidation. Bulletin of the National Academy of Sciences of Ukraine. Vol.11: 43-52. [in Ukrainian].
} 
former colonial countries, which strengthened relations with the USA as a result of gaining independence from the former metropolises.

4. 19 associations were selected for the purpose of research of processes of establishment and development of regional associations; 13 from them are integration established on the basis of regional trade deals concerning creation of free trade area and belong to the continents of Eurasia, North and Latin America and Africa; inter-governmental organization SCO; trans-regional integration associations TPP, the Council of Mutual Economic Assistance and T-TIP; trans-continental associations APEC and BRICS.

5. FTA NAFTA is the most powerful among regional integration associations due to the USA; the economic and monetary union EU is in the second place. NAFTA greatly fails to keep pace with EU according to the form of integration; EEU is at the stage of economic union. However, it lags EU, without mentioning NAFTA according to the indicators. The rest of associations are free trade areas and customs unions according to the form of integration and they greatly fail to keep pace with EU according to economic indicators.

6. ASEAN is a platform for integration processes in APR; it has signed free trade agreements and strategic partnership with all the greatest economies in Asia, where the competitive struggle between the USA, Japan, China, India, RF and EU takes place. Influence of the USA on the processes in Asia, in particular, in APR, is related to the implementation of TPP, and the influence of Japan and China is related with the Council of Mutual Economic Assistance and the project «One belt - one road». The implementation of the latter is closely related to the interests of EU, because its ultimate target is an establishment of reliable transport passage between the East and EU countries. T-TIP project in which the USA is interested is a competitor to Chinese global initiative «One belt, one road». The conflict of interests arises out of the mentioned projects.

7. North America consistently integrates with EU by the establishment of T-TIP. Mexico cooperates with the USA and Canada and is included into Pacific alliance; its integration future is indeterminate in connection with review of NAFTA agreement.

8. Associations oriented in their development to the USA, China, or the EU are established in Latin America. MERCOSUR is the center of integration in Latin America, implementing a policy of diversification of external relations, especially in the South-South direction; it resists the monopolistic domination of the USA both in the continent and across the globe. The leading country in the continent, Brazil, is a member of BRICS, which is formed as a bloc of countries opposed to the USA + EU bloc. 
9. There has been observed a competition between EU, PRC and the USA in the influence on the processes of regionalization in Africa. EAC, COMESA, SADC and ECOWAS are the main associations of Africa. Leading country of Africa, the Republic of South Africa, is a member of BRICS. The tripartite free trade area - EAC, COMESA, SADC was signed.

10. The processes of development of both regional and trans-regional associations result in keen competition between the USA and China. Association of the USA and EU is a bloc of countries of the Occidental civilization, and BRICS is a bloc of countries of not the Occidental civilizations (the USA + EU - BRICS). The course of regional integration processes in the global economy gives reason to come to conclusion that, for the purpose of prevention of conflicts and collisions, it is necessary to create the system of consensus regulation of global economy and to pivot from the existing ideology of maximization of satisfaction of material needs that will always lead to rise in inequality due to lack of availability of resources for production of goods and services.

11. The future demands the formation of a polycentric and multicivilizational global system whose functioning will be based on the nonhegemony of a particular country or civilization, and the concerted, compromise adoption of consensus decisions in the interests of all existing civilizations, cultures and peoples.

\section{References}

1. Aleshin, K. (2018). The African vector of the European Union foreign policy: past and present. Asia and Africa today. Vol. № 3:28-31.

2. Amin, S. (2010). Exiting the crisis of capitalism or capitalism in crisis. Globalizations. Vol.7, Issue 1-2: 261-273.

3. Analytical report to the Annual Message of the President of Ukraine to the Parliament of Ukraine «On the internal and external state of Ukraine in 2017». Kyiv: National Institute for Strategic Studies, 2017. [in Ukrainian].

4. Asia-Pacific Economic Cooperation. Key indicators database. StatsAPEC: http: / / statistics.apec.org/index.php/apec_psu/index_noflash

5. Bessarab, T., \& Tsybukh, I. (2017). Development, peculiarities of partnership and importance of Brazil's membership in BRICS. Bulletin of the National University «Lviv Politechnics». Political sciences. Vol.3, Issue 1: 1-6. [In Ukrainian].

6. Bilorus, O.G. (2016). The economic globalistics. The world system of globalism. Kyiv: University «Ukraine». [In Ukrainian].

7. Bone, J. (2012). The deregulation ethic and the conscience of capitalism: how the neoliberal 'free market' model undermines rationality and moral conduct. Globalizations. - 2012. - Volume 9, Issue 5: 651-665.

8. Bowen H.P., Sleuwaegen L. (2007). European integration: the third step. International Economics and Economic Policy. Vol. 4. Issue 3: 241-262. 
9. Bulatova, O., Kozak, Yu., Krysovatyi, A., Savel'ev, E. (2014). New world economic order and global challenges for Ukraine: monograph. Ternopil: Ternopil National Economic University. [in Ukrainian].

10. Bulatova, O.V. (2012). Regional component of the global integration processes: monograph, Donetsk: Donetsk National University. [In Ukrainian].

11. Butorina, O.V.. \& Kaveshnikova, N. Yu. (2017). European integration. Moscow: Aspect Press. [In Russian].

12. Chen, J. (2011). Factors shaping regional integration in Europe, Asia and Africa: the validity of competing theories. Alberta (Canada): University of Lethbridge.

13. Chuzhykov, V. (2016). Regional policy of the European Union. Kyiv: Kyiv National Economic University. [in Ukrainian].

14. Filipenko, A.S., Budkin, V.S., \& Dudchenko, M.A. (2004). International integration processes of today: monograph. Kyiv: Znannya Ukrainy. [in Ukrainian].

15. Green, J.K. (2016). Rising powers and regional orders: China's strategy and cross-strait relations. Globalizations. Volume 13, Issue 2: 129-142.

16. Guzhva, I. Yu. (2016). Ukraine's participation in free trade and the possibilities of adaptation of the national economy to the conditions, formed as the result of the megaregional trade blocks formation. Scientific Bulletin of the International Humanitarian University. Series: Economy and management. Odessa. Vol.15: 12-16. [in Ukrainian].

17. Hamilton-Hart N. (2003). Asia's new regionalism: government capacity and cooperation in the Western Pacific. Review of International Political Economy. Vol.10. Issue 2: 222-245.

18. Hettne, B. \& Soderbaum, F. (2000). Theorising the rise of regionness. New Political Economy. Vol. 5, Issue 3: 457-472.

19. Ivasechko, O. (2015). ASEAN and the EU in comparison: geoeconomical and institutional aspects Bulletin of the National University «Lviv Politechnics». Political sciences. Vol.1, Issue 2: 27-32. [in Ukrainian].

20. Kalashnikov, A.V. (2005). Confrontation between NATO and Warsaw Pact (1949-1991): dissertation for PhD in History. Lviv: National University «Lviv Politechnics». [in Ukrainian].

21. Karabaza, I.A., \& Klipo, M.S. (2017). The development tendencies of the BRICS countries and their influence on the modern international economic relations. Prychornomorsky economic studios. Vol. 15: 6-9. [in Ukrainian].

22. Khalina, O.V. (2018). Unevenness of economic development of the world countries as the main problem of today. Businessinform. Vol 5: 15-20.

23. Kheyfets, B. (2016). Transregional reformatting of the global economic space. Moscow: The Institute of Economy, Russian Academy of Sciences. [In Russian].

24. Kheyfets, B. (2016). Transregionalisation of global economic space. Society and economy. Vol.6: 20-42. [In Russian].

25. Korinets, G.B., Fleychuk, M.I., \& L'vivska, K.A. (2011). The importance of Ukrainian-Asian relations in the conditions of strengthening globalization processes. Bulletin of the National Lisotechnichny University of Ukraine. Vol. 21.9: 367-372. [in Ukrainian].

26. Krysovatyi, A.I., \& Savel'yev, E.V. (2016). Regional transformations in world and Ukrainian dimensions: monograph. Ternopil: Ternopil National Economic University. [in Ukrainian]. 
27. Kryvenko, N.V. (2017). The peculiarities of the development of integration blocs. Scientific notes of the National University of «Ostroz'ka academy». Series «Economy». Vol. 6(34): 4-7. [in Ukrainian].

28. Lileyev, I.L. (2015). EU and Africa: time to change priorities. Asia and Africa today. Vol.4: 7-10. [in Russian].

29. Lukianenko, D.G. Global economic integration. Kyiv: National textbook, 2008. [In Ukrainian].

30. Makedon, V.V. (2016). The growing significance and prospects for the BRICS countries in the system of the world economy. Mukachiv State University. Vol.4: 55-61. [In Ukrainian].

31. Mardashev, A.A. (2012). China's support to the African countries. Bulletin of Moscow State Institute for International Relations. Vol. 2(23): 59-69. [In Russian].

32. Marynina, S.V. (2013). The peculiarities of the integration development in the Asia-Pacific region. The Economic annals XXI. Vol. №1-2(2): 3-6. [In Ukrainian].

33. Mittelman, J.H. (2013). What's in a name? Global, international and regional studies. Globalizations. Volume 10, Issue 4: 515-519.

34. Mogherini F. Foreword. Global Strategy of the European Union on the foreign policy and security policy. Available at: http: / / eeas.europa.eu

35. Novitsky, V.E. (2004). Economic resources of civilization development. Kyiv: National Aviation University. [in Ukrainian].

36. Novitsky, V.E. (2007). Regulation strategies of the open economic systems and global competition for resources. Economy of Ukraine. Vol.7: 4-14. [in Ukrainian].

37. Petukhova, V.O. (2016). Analysis of foreign trade relations of the national economies and Ukraine in the global system of international trade. Scientific Bulletin of Uzhhorod National University. Series: International economic relations and world economy. Vol. 6, part 2: 149-155. [in Ukrainian].

38. Puriy, M.R. (2017). Hegemony in theory and practice of international relations: abstract of dissertation for $\mathrm{PhD}$ in Political Sciences. Chernivtsi: Chernivtsi National University named after Yuriy Fed'kovych. [in Ukrainian].

39. Pyrozhkov, S.I., Khamitov, N.V., (2017). Ukrainian society on its way to consolidation. Bulletin of the National Academy of Sciences of Ukraine. Vol.11: 43-52. [in Ukrainian].

40. Radzievska, S. (2016). Global Crisis, financialization and technological development. International Economic Policy. №24: 124-154.

41. Radziyevska S., Us I., Pokryshka D. (2017). Global dominates of China's development. International Economic Policy. № 26: 134-163

42. Reznikova, N.V., Ivaschenko, O.A. (2016). Development of trade liberalization in the countries of periphery: prospects for economic integration of Jordan. Economy and state. Vol.11: 19-24.

43. Robinson, W.I. (2013). Global capitalism and its anti-'human face': organic intellectuals and interpretations of the crisis. Globalizations. Volume 10, Issue 5: $659-671$

44. SADC-EAC-COMESA Tripartite Free Trade Area. Legal texts and policy documents / Tralac trade law centre. Available at: www.tralac.org

45. Sardak, S.E. (2016). The potential of economic development of ASEAN. Eastern Europe: economy, business and management. Vol.5(05): 41-44. [In Ukrainian].

46. Shergin, S.O. (2015). Dilemma of Asia-Pacific regionalism. Scientific Bulletin of the Diplomatic academy of Ukraine. Vol. 22(2): 36-49. 
47. Shnyrkov, O.I., Filipenko, A.S., \& Rumyantsev, A.P. (2013). Free trade areas at the beginning of $21^{\text {st }}$ century: monograph. Kyiv: Kyiv University. [in Ukrainian].

48. Shnyrkov, O.I., Filipenko, A.S., Zablotska, R.O. (2016). Development of the modern forms of the international economic integration in the beginning of the $21^{\text {st }}$ century: monograph. Kyiv: Kyiv University. [In Ukrainian].

49. Sidenko, V.R. (2011). Globalization - European integration - economic development: Ukrainian model. In two volumes. Kyiv, Fenix Publ. Volume 2: European integration and economic development. National Academy of Sciences of Ukraine; Institute for Economics and Forecasting. [In Russian].

50. Smoliy, A.V. (2016). Development of the Latin-American customs unions at the modern stage. Scientific Bulletin of Uzhhorod National University. Series: Law Studies. Vol. 40, Issue 2: 153-157. [In Ukrainian].

51. Taylor, I. (2003). Globalization and regionalization in Africa: reactions to attempts at neo-liberal regionalism. Review of International Political Economy. Vol. 10. Issue 2: 310-330.

52. The European idea // Historical events in the European integration process (1945-2014). Available at: http://www.cvce.eu

53. The Marshall Plan and the establishment of the Organization for European Economic Cooperation // Historical events in the European integration process (1945-2014). Available at: http:/ / www.cvce.eu

54. The Shanghai Cooperation Organization. Available at: http://eng.sectsco.org

55. Trade and development report 2017. Beyond austerity: towards a global new deal. Overview. - UNCTAD. - New York and Geneva, 2017. - P. 23-29.

56. UNCTAD Handbook of Statistics 2016. United Nations: N.Y. and Geneva, 2017. - 246 p.

57. UNCTAD Handbook of Statistics 2017. United Nations: N.Y. and Geneva, 2018. - $102 \mathrm{p}$.

58. Urnov, A.Yu. (2015). Summit USA-Africa. Asia and Africa today. Vol.1:2-7. [In Russian].

59. Us, I.V. On peculiarities of the foreign economic policy of Ukraine in the conditions of creation of new integration mega-blocks. Analytical notes. Available at: http://www.niss.gov.ua/articles / 1553

60. Wahl, P. (2017). Between Eurotopia and nationalism: a third way for the future of the EU. Globalizations. Volume 14. Issue 1: 157-163.

61. Wallace, H. (2000). Europeanisation and globalisation: complimentary or contradictory trends? New Political Economy. Volume 5, Issue 3: 369-382.

62. Wallerstein, I.(2007). Globalization or the age of transition? A long-term view of the trajectory of the world-system. Globalization and Economy. Vol. 1. Globalizing Markets and Capitalism. Ed. by P. James, B.K. Gills. - Los Angeles: Sage publications, 2007 (Central currents in globalization): 401-416.

63. Witkowska, J. (2016). Integration processes in the global economy: current state and prospects. The cases of the European Union, ASEAN Economic Community, and NAFTA. Comparative Economic Research. Vol.19, № 4: 47-65.

64. World Trade Organization. Regional trade agreements information system. Available at: http:// rtais.wto.org

65. World trade statistical review 2017. - Geneva: World trade organization, 2018. -177 p.

The article was received by the editorial board on 03.09.2018 